som klart overlapper med Pintos historie og problematik.

Selv om forfatteren ikke er særlig kendt uden for Paris, har han et solidt værk bag sig, siden han gik fra at være filosof til sociolog med specialisering i de intellektuelles og filosofiens sociologi. Han har bl.a. med tyve års mellemrum udgivet bøger om samtidens franske filosofi i sociologisk belysning, dels i Les philosophes entre le lycée et l'avantgarde (1987), dels i La Vocation et le métier de philosophe (2007). Den foreliggende bog minder dog mere om det store overblik, som han fremlagde i sin bog om Nietzschereceptionen i Frankrig i det tyvende århundrede, Les Neveux de Zarathoustra (1995), som jeg har anmeldt i K \& K $(78,1996)$.

NICOLAI VON EGGERS

\section{Sociologisk leksikon}

Steen Nepper Larsen \& Inge Kryger Pedersen (red.), Sociologisk leksikon, Hans Reitzels Forlag, 795 sider, 498 ker.

Når man bladrer i gennem Sociologisk Leksikon er det svært at få armene ned - selvom det er nødvendigt, hvis man vil bladre videre. Sociologisk Leksikon er ganske enkelt godt skrevet, godt disponeret og godt sat op. Artiklerne er som oftest omkring en tredjedel A4-side lange, men der findes opslag på op til to siders længde. Som det også bemærkes $\mathrm{i}$ forordet tager værket hermed både udfordringen fra Wikipedia og fra mere klassiske opslagsværker seriøst. Det medfører, at leksikonet er gennemført sociologisk i sine valg og sine vinklinger - hvorved det adskiller sig fra ethvert andet opslagsværk - og at leksikonets opslag i modsætning til Wikipedias på en gang er korte, skarpe, tankevækkende og præcise. At dette kan lade sig gøre beror udover kompetente bidrag og tekstredaktion på et for et opslagsværk særdeles modigt valg: I stedet for troskyldigt at opremse et hav af synspunkter på et givent begreb, præsenteres læseren fra starten for en (omend sober og åben) læsning. Eksempelvis starter opslaget 'Stat' med en definition fra Weber, suppleret af Bourdieu, går over en kort etymologi til en forlænget version af Foucaults statsgenealogi, inden vi slutter med tre perspektiver på nutidens nationalstat. Et andet eksempel er 'etnologi', hvor man i stedet for en klassisk videnskabelig selvforståelse, får slået fast, at etnologi er "udsprunget af 1800-tallets central- og nordeuropæiske nationaliseringsprocesser" i modsætning til antropologien, som er "udsprunget af koloniseringsprocesserne". Om det præcis hænger således sammen, skal jeg ikke gøre 
mig til dommer over, men etnologiens historico-socio-kulturelle herkomst er da en interessant betragtning at få med ind over etnologiens arbejdsmetoder og genstandsområder. Eksemplerne illustrerer, at der ikke blot er tale om et sociologisk opslagsværk, men at der arbejdes sociologisk i opslagsværket, og at dette arbejde i særlig grad er kritisk sociologisk. Og klart nok, for sociologien kan aldrig i sin fremstilling være objektiv i naturvidenskabelig forstand (og det kan naturvidenskaben måske heller ikke, vil man opdage, hvis man slår op på side 758: 'Videnssociologi'). Denne vinkling kunne få en diabolsk anmelder til at se værket som et kampskrift for kritisk sociologisk forskning pakket ind $i$ et lækkert cover af skinbarlig uvildig sandhed. Heldigvis er det jo selve sociologibegrebet, der er i spil, så i selve titlens mening, "Sociologisk Leksikon", bliver man påbudt at forholde sig kritisk; der eksisterer andre måder at forstå statsbegrebet på.

Som tidligere nævnt, skal man måske i endnu højere grad forstå, at der er tale om et sociologisk leksikon $\mathrm{i}$ artiklernes indhold end $\mathrm{i}$ deres udvalg. Leksikonet kommer imponerende bredt omkring med opslag om såvel teoretiske kernebegreber og almenbegreber, som psykologer og filosoffer - i den mere kuriøse afdeling kan nævnes et opslag viet specifikt til Heideggers begreb 'Sein'. Begrebet sættes dog (tilnærmelsesvis) ind $\mathrm{i}$ en sociologisk sammenhæng, og det viser at opslagsordene ikke er givne for læseren på forhånd - der kan være en vis glæde $i$ at bladre leksikonet igennem for at blive introduceret for alt fra 'chi2-test og 'exogami' til 'redundans' og 'totemisme'. $\mathrm{Nu}$ har jeg af magelige grunde ikke læst alle 2270 opslag fordelt på 800 sider, men generelt emmer artiklerne af et - for et opslagsværk atypisk - engagement, der gør dem læsevenlige og vedkommende. Som en ekstra feature gengives nederst i artiklen opslagsordet i sin engelske form, hvilket er meget praktisk, hvis man skal bruge begrebet $i$ en engelsk artikel, opgave el. lign. - men som også vidner om den stigende angloficering af selve vores (kritiske) tænkemåde.

Hvis man endelig skulle indvende noget mod værket, må det være den bevidste udeladelse af nulevende danske sociologer. Beslutningen er forståelig, for det ville være svært at gøre disse artikler sobre, beslutte hvem der skulle med og desuden ville disse artikler hurtigt gøre hele værket uddateret. Men det ville nu have været en god hjælp for dem, som på baggrund af værket skulle få lyst til at engagere sig i sociologisk forskning. 
Her må man i stedet ty til den ultrakorte præsentation af værkets omkring 100 bidragydere, der tegner et nogenlunde billede af hvad der foregår på det sociologiske felt i Danmark.

Bogen henvender sig ifølge forordet til 3.g'eren, den forsteårsstuderende, journalisten, den professionelle sociolog og den almindeligt nysgerrig. Ud fra denne betragtning er opslagsværket ualmindeligt vellykket, og jeg håber inderligt, at opslagsværket vil komme så vidt omkring som intenderet, for i så fald tegner fremtiden for den offentlige debat i Danmark en hel del lysere. 